\title{
Sublethal effects of the herbicide diuron on the freshwater snail Physella acuta
}

\author{
Julio C. López-Doval ${ }^{1, *}$, Montserrat Poquet $^{2}$ and Isabel Muñoz ${ }^{1}$ \\ ${ }^{1}$ Department of Ecology, University of Barcelona, Av. Diagonal, 645, 08028 Barcelona, Spain. \\ ${ }^{2}$ Department of Cell Biology, University of Barcelona, Av. Diagonal, 645, 08028 Barcelona, Spain. \\ * Corresponding author: jclopezdoval@usp.br
}

Received: 14/10/2013

Accepted: 03/04/2014

\begin{abstract}
Sublethal effects of the herbicide diuron on the freshwater snail Physella acuta

Diuron is an herbicide present in European rivers at concentrations of environmental concern. Its effects on pulmonate gastropods are not well studied. A 16-day bioassay at five concentrations, including realistic ones, was performed with the freshwater snail Physella acuta to determine the effects of this herbicide on reproductive and metabolic traits as well as tissues and organs. The responses measured were survival, biomass, reproduction, motility, carbon (C) and nitrogen (N) contents and histology. Diuron at concentrations similar to those found in freshwater environments $\left(9.5 \mu \mathrm{gL}^{-1}\right)$ causes sublethal effects in the freshwater snail. Results showed an increase in the C:N molar ratio at 9.5, 46.5 and $1172.5 \mu \mathrm{gL}^{-1}$ and in the volume of secretory cells in the tegument at the same concentrations. The number of egg clutches increased slightly from a concentration of $46.5 \mu \mathrm{gL}^{-1}$, but this was not statistically significant. No effects on locomotor ability, biomass or survival, even at the highest concentration $\left(1172.5 \mu \mathrm{gL}^{-1}\right)$, were detected.
\end{abstract}

Key words: Physella acuta, Pulmonata, diuron, histopathology, sub-lethal effects, ecotoxicology.

\section{RESUMEN}

Efectos subletales del herbicida diuron en el caracol de agua dulce Physella acuta

El diuron es un herbicida presente en ríos europeos a concentraciones de relevancia para el medio. Sus efectos en moluscos pulmonados no están bien estudiados. Con el caracol de agua dulce Physella acuta, se realizó un bioensayo de 16 días de duración y con diferentes concentraciones, incluyendo, concentraciones de relevancia ambiental. Se estudiaron los efectos en el metabolismo y la reproducción, así como, en tejidos y órganos. Las respuestas medidas fueron la supervivencia, la biomasa, la reproducción, la motilidad, contenido de carbono $(C)$ y nitrógeno $(N)$ y la histología. El diuron a concentraciones similares a las encontradas en ambientes acuáticos $\left(9.5 \mu \mathrm{gL} \mathrm{L}^{-1}\right)$ causa efectos en el caracol de agua dulce. Los resultados muestran un incremento en la relación molar C: $N$ en las concentraciones de 9.5, 46.5 y $1172.5 \mu g L^{-1}$ y en el volumen de las células secretoras en el tegumento a estas mismas concentraciones. El número de puestas se incrementó ligeramente a partir de los $46.5 \mu \mathrm{gL} \mathrm{L}^{-1}$ pero sin significancia estadística. No se observaron efectos en la capacidad locomotora, la biomasa o la supervivencia, incluso en la concentración más alta $\left(1172.5 \mu \mathrm{gL}^{-1}\right)$.

Palabras clave: Physella acuta, Pulmonata, diuron, histopatología, efectos subletales, ecotoxicología.

\section{INTRODUCTION}

Herbicides are one of the most common pollutants in rivers. They reach fluvial systems via runoff from crop areas, spray drift, leaching or accidental spills (Thurman et al., 1991). Diuron ( $N$-(3,4-diclorophenyl)- $N, N$-dimethylurea CAS $\left.\mathrm{N}^{\mathrm{o}} 330-54-1\right)$ is a biologically active pollutant of 
the phenylamide family of herbicides. It is a nonionic compound having moderate water solubility $\left(42 \mathrm{mgL}^{-1}\right.$ at $\left.20^{\circ} \mathrm{C}\right)$ and a moderate octanolwater partition coefficient $\left(\log K_{o w}=2.6\right)$, as well as a negligible rate of hydrolysis at neutral pH (Giacomazzi \& Cochet, 2004).

In European rivers flowing through crop areas, the reported concentrations of diuron ranged in one study from 2.1 to $36 \mu \mathrm{gL}^{-1}$ (Tlili et al., 2008). Rodríguez-Mozaz et al. (2004) found a maximum concentration of $0.239 \mu \mathrm{gL}^{-1}$ in the Llobregat River (NE Spain), but diuron pulses of up to $134.0 \mu \mathrm{gL}^{-1}$ have been described during flooding events in vineyard catchments in France (Proia et al, 2011). The presence and concentration of diuron would be expected to depend on the season as well as on the intensity and frequency of rainfall. Diuron can remain in the environment from one month to one year. Hydrolysis of diuron produces 3,4-dichloroaniline, which is also toxic (Giacomazzi \& Cochet, 2004). Diuron was included on the Priority Hazardous Substance list by the European Commission (Directive 2008/105/EC), and its use has been progressively reduced (European Commission, 2007).

Toxic effects of diuron have been reported on freshwater invertebrates, albeit at high concentrations. Nebeker \& Schuytema (1998) found that the growth and survival of Lumbriculus variegatus were affected by a diuron concentration of $3.5 \mathrm{mgL}^{-1}$, Hyalella azteca mortality occurred at $15.7 \mathrm{mgL}^{-1}$, Chironomus tentans survival decreased at $3.4 \mathrm{mgL}^{-1}$ and growth of the freshwater snail Physa gyrina decreased at $22.8 \mathrm{mgL}^{-1}$; all concentrations are expressed as the lowest adverse effect observed. Christian \& Tate (1983) described the $\mathrm{LC}_{50}$ for diuron at $15.3 \mathrm{mgL}^{-1}$ in Lymnaea spp. for a $96 \mathrm{~h}$ exposure. Sanders \& Cope (1968) determined that mortality $\left(\mathrm{LC}_{50}\right)$ occurred in a stonefly population at $3.6 \mathrm{mgL}^{-1}$ in a $24 \mathrm{~h}$ experiment. However, Noguerol et al. (2006) reported endocrine disrupting effects at a much lower diuron concentration $\left(0.26 \mathrm{mgL}^{-1}\right)$ in recombinant yeast cells. These results indicate that sublethal effects of diuron can occur in animals.
Diuron produces mortality at high concentrations. However, these concentrations are not representative of natural conditions. Sublethal concentrations of pesticides can alter several individual traits through effects on neurotransmitters, hormones, immune response, reproduction, physiology, morphology or behaviour (Relyea \& Hoverman, 2006). To date, these endpoints have not been studied in invertebrates for the herbicide diuron (Giacomazzi \& Cochet, 2004).

Studies of molluscs are important because they play an important role as consumers of primary producers and as sources of energy to higher trophic levels in rivers. In terms of biomass and abundance, molluscs could be dominant in some aquatic ecosystems (Lagadic et al., 2007). They represent an appropriate experimental model because they are sensitive to endocrine disruptors (Matthiessen \& Gibbs, 1998, DeFur et al. 1999, Schmidt et al., 2010, De Castro-Català et al. 2013).

This work focused on the sublethal effects of diuron. For this purpose, we assessed the effects of diuron concentrations ranging from 9.5 to $1172.5 \mu \mathrm{gL}^{-1}$ on the freshwater snail Physella acuta, a common hermaphroditic snail in European rivers. The endpoints selected have ecological relevance and are likely to be damaged or impaired as a result of continuous exposure of the organisms to low concentrations of the toxicant. We analysed the effects of diuron on different organs and metabolism by studying histology and $\mathrm{C}: \mathrm{N}$ content responses, respectively. Locomotive skills and reproductive characteristics (numbers of eggs and egg clutches) were also investigated to detect possible sublethal effects on the nervous system or reproduction. Impairment of reproductive endpoints and histological damage to gonads, as well as morphological modifications of the genitalia, can be indicators of endocrine-disrupting effects (Oehlmann et al., 2000; Schulte-Oehlmann et al., 2000; Czech et $a l ., 2001)$. To the best of our knowledge, the effects of diuron on these endpoints have rarely been studied in freshwater snails. Our hypothesis is that chronic exposure to diuron concentrations of environmental relevance could cause sublethal effects and impairment to endpoints of ecological relevance. 


\section{MATERIALS AND METHODS}

\section{Experimental design}

Adults of the freshwater snail Physella acuta (Draparnaud, 1805) were collected in an unpolluted stream and acclimatised to laboratory conditions for 10 days. Individuals were kept in aquaria with dechlorinated tap water (by means of a carbon filter) and fed TetraMin fish food every two days.

Diuron $(\geq 98 \%)$ was purchased from Riedelde-Häen (Seelze, Germany) (D2425). A stock solution with methanol was prepared $\left(1 \mathrm{gL}^{-1}\right)$, and working solutions were prepared by diluting the stock solution with Milli-Q water. The maximum percentage of methanol added with the toxicant in the aquaria was $0.07 \%$ with regard to total water volume (3L). From the initial stock solution, 4 solutions were prepared to apply the correct amount of diuron to each aquarium and achieve the correct dilution factor in the $3 \mathrm{~L}$ of water.

The tested nominal concentrations were 0 (control), 5, 50, 500 and $1000 \mu \mathrm{gL}^{-1}$. Experiments were performed in 15 glass aquaria (3 aquaria per treatment, where each aquarium was a replicate) filled with $3 \mathrm{~L}$ of dechlorinated tap water. Randomly, 17 snails of approximately the same size (mean shell length $8.37 \pm 1.07 \mathrm{~cm}$ ) were added to each aquarium and exposed to diuron for 16 days. Snails were fed daily in excess with TetraMin $(85.37 \pm 4.4 \mathrm{mg}$ in each aquarium). The food that was not ingested was removed from the bottom the next day before adding new food. Sufficient air to oxygenate the water was supplied by an air pump through glass tubes. The light:dark cycle was 16:8 $\mathrm{h}$. Water was changed twice a week (Monday and
Thursday). Water was totally removed and diuron was added to each aquarium to attain the desired concentrations.

The temperature, conductivity, $\mathrm{pH}$ and oxygen concentration of the water were measured daily with a multiparametric probe. The ammonia concentration was measured twice a week (Monday and Thursday) with a commercial kit (Merck Ammonium Test, 1.14428.0001). The concentration of diuron in exposed aquaria was measured four times during the experiment (Monday and Thursday). During the experiment, samples of water were analysed by HPLC-MS (Rodriguez-Mozaz et al., 2004) to confirm the presence of diuron in the water. During the experiment, the concentration of diuron in the water after a water change was analysed twice in all experimental conditions. The concentration of diuron in the water before a water change (3 or 4 days after water renewal) was analysed twice as well. Previous to the analysis, $1 \mathrm{~L}$ of water was concentrated by solid-phase extraction (SPE) cartridges (Lichrolut RP18). For analysis of the concentration of diuron after a water change or under the initial conditions, $1 \mathrm{~L}$ of initial water was taken. For analysis of the diuron in water before a water change, water was collected from the aquaria before disposal and $1 \mathrm{~L}$ was used for the SPE.

\section{Endpoints}

\section{Mortality}

Mortality was checked daily and dead individuals were removed from the aquaria. We considered an individual to be dead if it did not withdraw its body into its shell when its foot was touched.

Table 1. Water characteristics during the experiment. Data are shown as mean value and standard deviation in brackets. Características del agua durante el experimento. Se muestra valor medio y desviación estándar entre paréntesis.

\begin{tabular}{|c|c|c|c|c|c|}
\hline Nominal conc. $\left(\mu \mathrm{gL}^{-1}\right)$ & Real conc. $\left(\mu \mathrm{gL}^{-1}\right)$ & $\mathbf{T}^{\circ} \mathbf{C}$ & cond $\left(\mu \mathrm{Scm}^{-1}\right)$ & pH & $\mathrm{O}_{2} \%$ \\
\hline 0 & - & $18.5(1.3)$ & 437 (24) & $8.13(0.14)$ & $93.6(31.3)$ \\
\hline 5 & $9.46(0.32)$ & $18.2(1.3)$ & $432(22)$ & $8.10(0.14)$ & $101.7(22.1)$ \\
\hline 50 & $46.47(23.26)$ & $18.2(1.5)$ & $429(24)$ & $8.05(0.17)$ & $97.9(25.8)$ \\
\hline 500 & $592.50(71.24)$ & $18.4(1.4)$ & $432(22)$ & $8.06(0.17)$ & $101(21.5)$ \\
\hline 1000 & $1172.50(62.92)$ & $18.3(1.3)$ & $429(21)$ & $8.18(0.30)$ & $101.8(20.6)$ \\
\hline
\end{tabular}




\section{Reproduction}

Our measures of reproduction were the total number of egg sacs and the number of eggs per egg sac. Egg sacs were counted each day. During the experiment, clutches were removed carefully from each aquarium to count the numbers of eggs using a stereomicroscope $(\times 4$, Leica MZ95).

\section{Snail biomass and $C$ and $N$ contents}

These endpoints were measured at the end of the experiment. On day 16, all living individuals, with the exception of those to be used for histological analysis (7 or 9 per condition), were frozen in liquid $\mathrm{N}_{2}$ and stored (frozen in a $-80^{\circ} \mathrm{C}$ freezer) prior to analysis. Biomass was calculated as dry weight. After the shell was removed, organisms were desiccated in an oven at $70{ }^{\circ} \mathrm{C}$ to constant weight and then weighed. Two snails were taken randomly from each aquarium for $\mathrm{C}$ and $\mathrm{N}$ content analysis in each treatment (6 snails per treatment). All six individuals were ground together. From this homogenate, four analytical replicates were taken for analysis. The $\mathrm{C}$ and $\mathrm{N}$ analyses were performed with a NA $1500 \mathrm{Au}$ tomatic Nitrogen Analyser (Carlo Erba Instruments) by means of total combustion of the samples and analysis of the resulting gases.

\section{Snail motility}

Snail motility was selected as a behavioural indicator of possible sublethal effects of diuron on locomotor ability, as has been explained in Rosés et al. (1999). Motility was estimated as the distance covered by a snail in a fixed time $\left(\mathrm{cms}^{-1}\right)$. For this purpose, a reticulated template with squares of $5 \times 5 \mathrm{~mm}$ was placed below the transparent base of the aquarium. Two snails were chosen randomly in each aquarium and their movement was monitored (6 individuals per treatment). Individuals were not handled and were chosen visually. Their speed was measured in the same aquarium so as not to disturb the organisms. Once a snail was chosen, we monitored its movement during the 60 seconds. The template was helpful for following the trajectory of the snail while the ob- server drew the same trajectory on another template. Motility was measured on days 9 and 16 in the absence of food ( $1 \mathrm{~h}$ after a water change) to force the snails to move.

\section{Histological damage}

A histological study was performed on individuals from the control and exposed conditions (a minimum of 3 individuals per treatment from different replicates) at the end of the experiment. The entire body was examined. Particular attention was given to the reproductive organs, lung, digestive gland and foot tegument. Histological alterations and damage were analysed in comparison to the control and based on previous experience in the study of the histology of molluscs. Individuals without shells were fixed in $4 \%$ formaldehyde overnight. Samples were then rinsed with tap water for an hour. A 2-h bath in $70 \%$ ethanol and a 1-h bath in $96 \%$ ethanol were performed to dehydrate the sample. A final 2-h bath in butanol was administered before overnight incubation in butanol and paraffin. Finally, samples were embedded in paraffin. Paraffin sections $(7 \mu \mathrm{m})$ were obtained using an Anglia Scientific 0325 rotary microtome and stained with hematoxylin-eosin (H\&E). In addition, to detect mucous secretions by the tegument cells, sequenced sections were stained using a periodic acid-Schiff's reagent (PAS) technique (McManus, 1948). Individuals were fixed and dehydrated as explained above. Subsequently, deparaffinised sections were hydrated and oxidised with periodic acid, followed by a treatment with Schiff's reagent. A permanent preparation was then made. All stained sections were studied under an Olympus CX 41 light microscope, and digital images were captured with an Altra 20 digital camera.

\section{Statistical analysis}

Statistical analyses were performed using SPSS 15.0 software. Homoscedasticity of the data set was confirmed by Levene's test. Comparison of data was performed using a one-way ANOVA with treatments as a fixed factor; a $p$ value $<0.05$ 
Table 2. Mortality (total individuals and percentage) in each treatment at the end of the experiment. Data are shown as mean values of dead individuals with standard deviation in brackets. Number of replicates was 3 , and each aquarium was a replicate. Mortalidad (número total de individuos y porcentaje) en cada condición al final del experimento. Los datos se muestran como valor medio y desviación estándar entre paréntesis. Número de réplicas igual a 3, cada acuario es una réplica.

\begin{tabular}{ccc}
\hline $\begin{array}{c}\text { Concentration } \\
\left(\boldsymbol{\mu g L ^ { - 1 } )}\right.\end{array}$ & $\begin{array}{c}\text { Dead } \\
\text { individuals }\end{array}$ & $\begin{array}{c}\text { Dead } \\
\text { individuals in \% }\end{array}$ \\
\hline $0 \mu \mathrm{gL}^{-1}$ & $8.33(2.08)$ & 49.02 \\
$9.5 \mu \mathrm{gL}^{-1}$ & $8.67(2.31)$ & 50.98 \\
$46.5 \mu \mathrm{gL}^{-1}$ & $7.67(2.52)$ & 45.10 \\
$592.5 \mu \mathrm{gL}^{-1}$ & $6.67(2.08)$ & 39.22 \\
$1172.5 \mu \mathrm{gL}^{-1}$ & $7.33(4.51)$ & 43.14 \\
\hline
\end{tabular}

Table 3. Mean velocities on day 9 and day 16, expressed as $\mathrm{cm} \mathrm{s}^{-1}$. Standard deviation is shown in brackets. Number of individuals studied in each condition was 6. Velocidad media en los días 9 y 16, expresada como $\mathrm{cm} \mathrm{s}^{-1}$. La desviación estándar se muestra entre paréntesis. El número de individuos estudiados en cada condición fue 6.

\begin{tabular}{ccc}
\hline $\begin{array}{c}\text { Concentration } \\
\left(\boldsymbol{\mu g L} \mathbf{L}^{-\mathbf{1}}\right)\end{array}$ & $\begin{array}{c}\text { day } \mathbf{9} \\
\mathbf{c m s}^{-\mathbf{1}}\end{array}$ & $\begin{array}{c}\text { day } \mathbf{1 6} \\
\mathbf{c m s}^{-\mathbf{1}}\end{array}$ \\
\hline 0 & $8.04(1.78)$ & $7.71(3.18)$ \\
9.5 & $6.77(1.95)$ & $9.73(4.58)$ \\
46.5 & $5.90(0.98)$ & $2.54(2.32)$ \\
592.5 & $5.18(3.12)$ & $6.31(5.02)$ \\
1172.5 & $7.77(3.25)$ & $5.16(4.00)$ \\
\hline
\end{tabular}

was considered for rejection of $H_{0}$. Multiple comparisons between treatments were performed using Dunnett's test, and significant differences were considered at $p<0.05$.

\section{RESULTS}

Physical and chemical parameters were constant throughout the experiment in all treatments (Table 1). Ammonium $\left(\mathrm{NH}_{4}^{+}\right)$concentrations never exceeded $0.3 \mathrm{mgL}^{-1}$ (data not shown). The concentration of diuron in water was constant throughout the experiment but slightly higher than nominal in three of the four concentrations tested. Nevertheless, diuron values maintained the same order of magnitude, and concentrations increased in accordance with the logarithmic relationship designed (Table 1). No loss of diuron from the water was observed over time. Owing to the use of dechlorinated tap water, and because diuron was not expected to be present, we did not analyse diuron content for the control treatment. Given that nominal and real concentrations were not equivalent, hereafter we refer only to real concentrations.

No differences in mortality were observed (Table 2) between treatments and the control. Despite the absence of significant differences in fertility, a slight increase in the total number of egg sacs at the end of the experiment was observed beginning at $46.5 \mu \mathrm{gL}^{-1}$ (Fig. 1A), whereas the number of eggs per egg sac remained equal in all treatments (Fig. 1B). Motility did not exhibit differences between days 9 and 16 or between treatments (Table 3). Biomass did not exhibit significant differences among treatments at the end of the experiment (Table 4). The average value of biomass ranged from $9.33 \pm 1.7 \mathrm{mg}$ of dry weight (control) to $12.34 \pm 3.43 \mathrm{mgDW}$ (9.5 $\mu \mathrm{gL}^{-1}$ treatment).

The C:N molar ratio of snails in the control treatment was $5.84 \pm 0.04$ (Table 4 ). The percentages of $\mathrm{C}$ and $\mathrm{N}$ in the control treatment were $47.65 \pm 0.32 \%$ and $9.51 \pm 0.08 \%$, respectively (Table 4). The carbon percentage decreased significantly in all concentrations compared to the control ( $F=17.09, p<0.001$, Dunnett's test), and the nitrogen percentage decreased significantly in all concentrations with the exception of the highest ( $F=63.08, p<0.001$, Dunnett's test). A significant increase in the $\mathrm{C}: \mathrm{N}$ molar ratio at concentrations of $9.5,46.5$ and $1172.5 \mu \mathrm{gL}^{-1}(F=$ $=76.37, p<0.001$, Dunnett's test) was observed.

The histological study of control and exposed organisms reveals changes in the tegument. In the foot's tegument, an increase in the size of mucous cells and an increase in the amount of secretory granules rich in mucopolysaccharides were observed in organisms exposed to 9.5, 46.5 and $1172.5 \mu \mathrm{gL}^{-1}$ of diuron (Fig. 2). The hypertrophy of these cells was characterised by a positive PAS reaction in many secretory granules of mucous cells. In the case of organisms studied from the treatment of $46.5 \mu \mathrm{gL}^{-1}$, the tegument also showed necrotised areas. During the experiment, an accumulation of mucus in the water was observed at $1172.5 \mu \mathrm{gL}^{-1}$. 

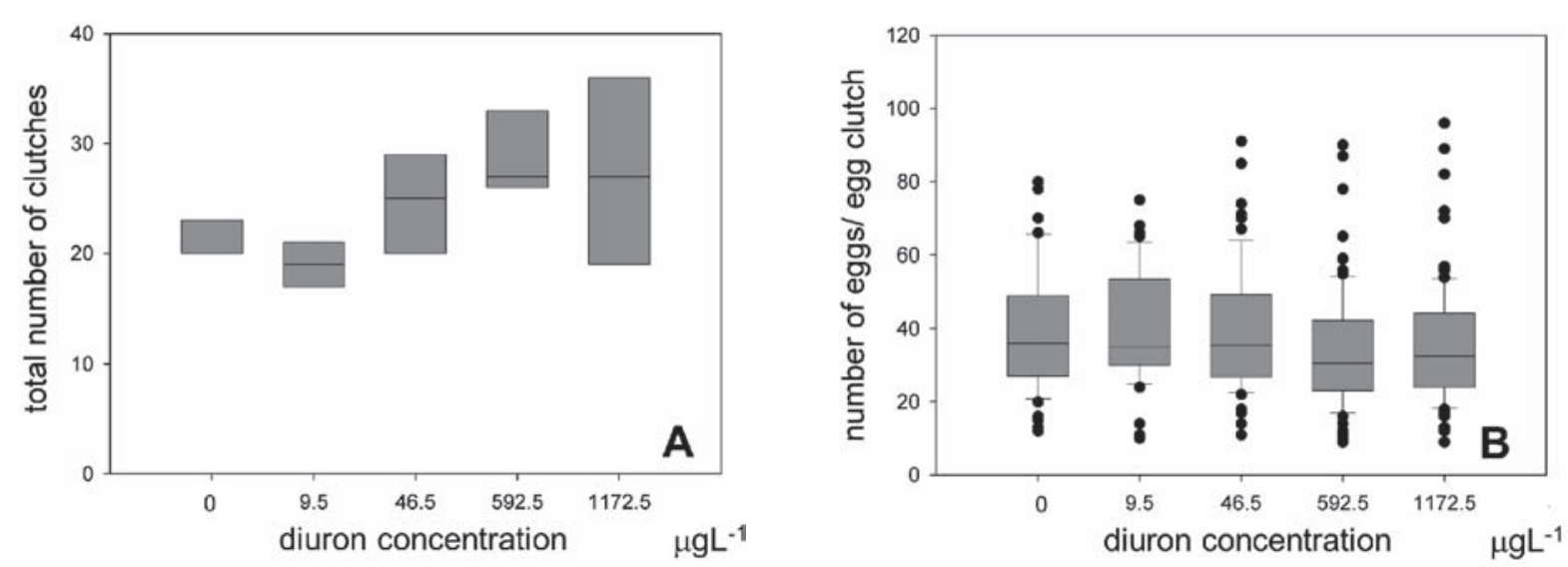

Figure 1. Reproductive response of snails exposed to several concentrations of diuron. Data are shown as box-plot graphs. Median is depicted, bottom and top of the box indicate the $25^{\text {th }}$ and $75^{\text {th }}$ percentiles, respectively, thin lines include the $90 \%$ of the data and points are outlier values. A: total number of egg sacs. B: number of eggs per egg sac. Respuesta reproductiva de los caracoles expuestos a varias concentraciones de diuron. Datos mostrados en gráficos box-plot. Se muestra la mediana, las partes inferior y superior de la caja representan los percentiles 25 y 75 respectivamente, las líneas incluyen el $90 \%$ de los datos y los puntos representan valores atípicos. A: número total de puestas. B: número de huevos por puesta.

\section{DISCUSSION}

This study offers an examination of the effects of several diuron concentrations on the freshwater snail P. acuta. The experimental treatments included concentrations of environmental relevance (from 2.1 to $36 \mu \mathrm{gL}^{-1}$; Tlili et al., 2008). Although no lethal effects were observed, sublethal effects were observed from $9.5 \mu \mathrm{gL}^{-1}$, including changes in the $\mathrm{C}: \mathrm{N}$ molar ratio and alterations in histology. The presence of diuron did not produce significant differences in mortality from the control. Nevertheless, mortality occurred at above $20 \%$ in the control group. Although the use of feral organisms increased the environmental relevance of the study, it could be a disadvantage. No effects on mortality were ex- pected, however, in view of the fact that previous works report mortality in other lymnaeid species at concentrations 15 times higher than ours (Christian \& Tate, 1983). Over the range of concentrations studied, diuron did not cause significant differences in biomass. Biomass decrease was found by Nebeker and Schuytema (1998) in juveniles of the freshwater snail Physa gyrina exposed to a concentration of $22.8 \mathrm{mgL}^{-1}$ for $10 \mathrm{~d}$, but that concentration also exceeds ours and would be unrealistic in comparison with real environmental conditions.

Although no effects of diuron on biomass were evident, changes in the $\mathrm{C}: \mathrm{N}$ molar ratio were observed. Values of the $\mathrm{C}: \mathrm{N}$ molar ratio in the control population agree with values found for freshwater molluscs in other studies (Evans-

Table 4. Mass in dry weight per individual, percentages of carbon and nitrogen and molar ratio. We show the mean value and the standard deviation in brackets. Asterisk marks significant differences with respect to the control ( $p<0.05$, Dunnett's test). Masa en peso seco por individuo, porcentaje de Carbono y Nitrógeno y relación molar. Se muestra valor medio y desviación estándar, entre paréntesis. El asterisco marca las diferencias significativas respecto al control ( $\mathrm{p}<0.05$ test de Dunnett).

\begin{tabular}{ccllc}
\hline Concentration $\left(\boldsymbol{\mu} \mathbf{g L}^{-\mathbf{1}}\right)$ & mg DWind & \multicolumn{1}{c}{ \% of C } & \% of N & C:N molar ratio \\
\hline 0 & $9.33(1.7)$ & $47.65(0.32)$ & $9.51(0.08)$ & $5.84(0.05)$ \\
9.5 & $12.34(3.43)$ & $45.31(0.19)^{*}$ & $8.75(0.07)^{*}$ & $6.04(0.03)^{*}$ \\
46.5 & $9.53(3.39)$ & $45.73(0.86)^{*}$ & $8.74(0.16)^{*}$ & $6.11(0.01)^{*}$ \\
592.5 & $10.68(3.24)$ & $46.72(0.17)^{*}$ & $9.28(0.03)$ & $5.88(0.04)$ \\
1172.5 & $9.56(2.78)$ & $46.47(0.25)^{*}$ & $9.39(0.05)$ & $5.77(0.02)^{*}$ \\
\hline
\end{tabular}


White et al. 2005; Jurkiewicz-Karnkowska, 2005). Fink and Von Elert (2006) explain that under natural conditions, Radix ovata can maintain a constant $\mathrm{C}: \mathrm{N}$ ratio independent of food composition. In the present study, all animals in all treatments were fed with the same quantity and quality of food. This observation suggests that the decrease in this percentage is due to the effect of diuron, although we cannot explain the mechanism. It is well known that xenobiotics could modify an organism's energy budget by altering energy acquisition or by increasing/decreasing the demand for energy used in reproduction, maintenance, growth or damage repair (Calow, 1991; Beyers et al., 1999; Barata et al., 2004). This alteration could impair the animal's fitness in natural conditions.

With reference to the study of histological damage, the organs selected were those that would potentially be affected by diuron: the foot and
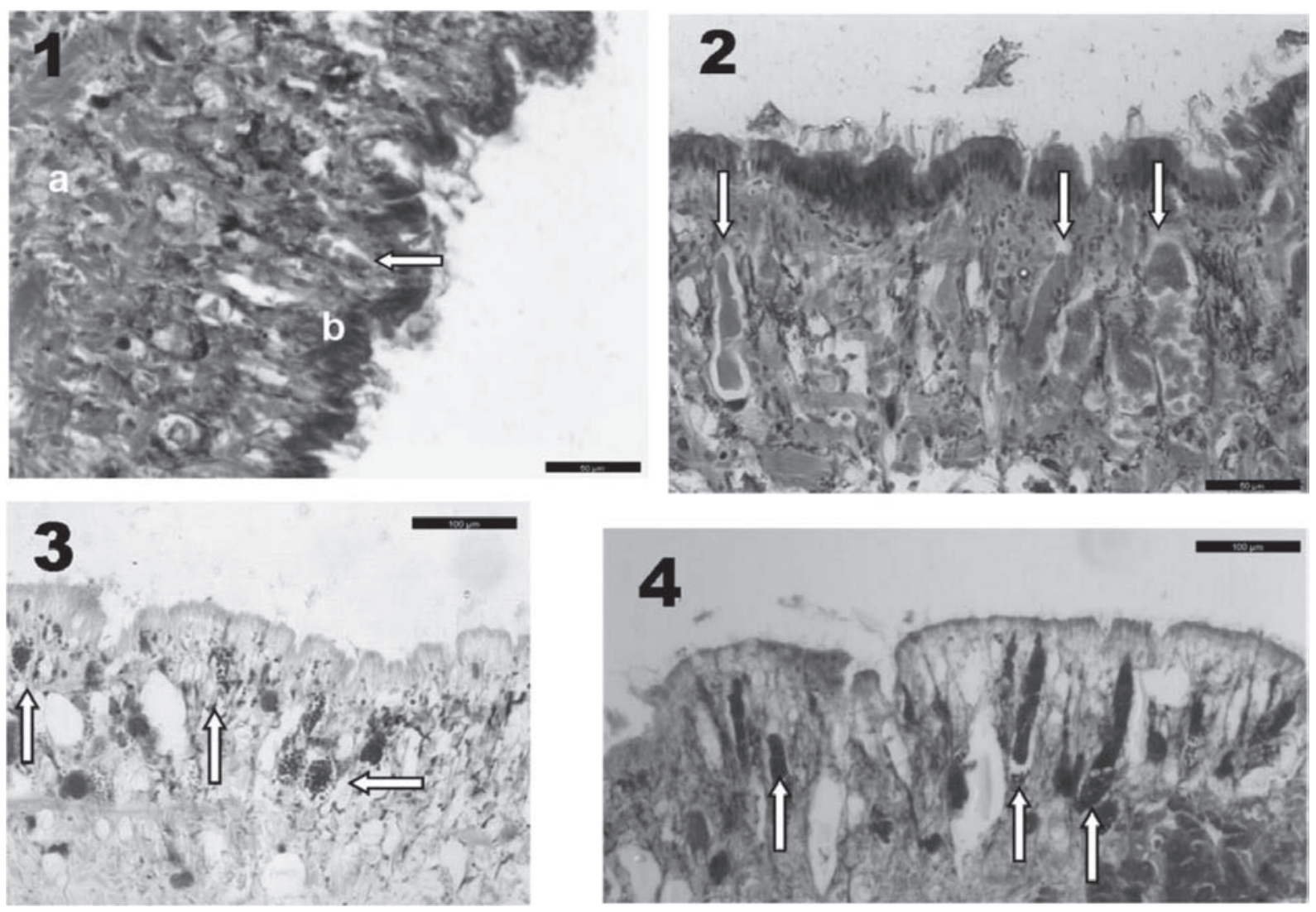

Figure 2. Hypertrophy observed in the tegument after exposure to $1172.5 \mu \mathrm{gL}^{-1}$ of diuron. Organisms exposed to diuron (pictures 2 and 4) exhibited an increase in the volume of mucous cells (marked by white arrows) in comparison with control ones (pictures 1 and 3). Hipertrofia observada en el tegumento después de la exposición a $1172.5 \mu \mathrm{gL} \mathrm{L}^{-1}$ de diuron. Los organismos expuestos (imágenes 2 y 4) al diuron mostraron un incremento en el volumen de las células mucosas (marcado mediante flecha) en comparación con los controles (imágenes 1 y 3 ). 1. Foot of control organism. (a) Muscle fibres, (b) ciliate epithelium with mucous cells (white arrow). $\mathrm{H} \& \mathrm{E}$, scale bar $=50 \mu \mathrm{m}$. Pie de organismo control. (a) Fibras musculares, (b) epitélio ciliado con células mucosas (flecha blanca). $H \& E$, barra $=50 \mu \mathrm{m}$. 2. Foot of exposed organism. The muscle fibres and epithelium layer are disorganised, there is an increase in the size of mucous cells (white arrows). $\mathrm{H} \& \mathrm{E}$, scale bar $=50 \mu \mathrm{m}$. Pie de organism expuesto. Las fibras musculares y la capa epitelial están desorganizadas, incremento de células mucosas (flecha blanca). H\&E, barra $=50 \mu m$. 3. Foot of control organism. Secretory granules in mucous cells can be observed (white arrows). PAS, scale bar $=100 \mu \mathrm{m}$. Pie de organismo control. Se pueden observar gránulos secretores en las células mucosas (flecha blanca). PAS, escala de la barra $=100 \mu m$. 4. Foot of an exposed organism to diuron. Increase of the volume of mucous cells (white arrows). PAS, scale bar $=100 \mu \mathrm{m}$. Pie de organismo expuesto al diuron. Incremento en el volumen de las células mucosas (flechas blancas). PAS, escala de la barra = $100 \mu \mathrm{m}$. 
mantle, because of direct contact; the digestive gland, because it is involved in detoxification and metabolisation, and gonads, because of the potential effects of diuron on fertility (Orton et al., 2009; Noguerol et al., 2007) and damage to gonads (severe testicular damage has been observed in vertebrates when exposed to diuron; Cardone et al., 2008). No damage or histological alteration was observed in our samples with the exception of a qualitative increase in the volume of mucous secretory cells in the tegument of organisms exposed to $9.5,46.5$ and $1172.5 \mu \mathrm{gL}^{-1}$. Similar observations have been reported by Cengiz et al. (2005) in the freshwater snail Galva truncatula exposed to $0.3 \mathrm{mgL}^{-1}$ of the herbicide endosulfan.

Histological effects of diuron in gonads have been reported (Cardone et al., 2008), and it is suspected to disrupt endocrine activity; for this reason, we studied reproductive parameters. Orton et al. (2009), in assays with recombinant yeast, found antiestrogenic activity of diuron at concentrations of $228.5 \mu \mathrm{gL}^{-1}$ (our test range was from 5 to $1000 \mu \mathrm{gL}^{-1}$ ) as well as inhibition of testosterone level and ovulation in Xenopus laevis at $14.6 \mathrm{mgL}^{-1}$. In other work with recombinant yeast (Noguerol et al. 2006), this pesticide activated the aryl carbon receptor at $260 \mu \mathrm{g}$ $\mathrm{L}^{-1}$. This change is associated with immune and endocrine disruption, reproductive toxicity and other malfunctions (Abbot et al., 1994, Connor et al., 1997). Those assays were performed using vertebrate receptors in yeast, but freshwater snails have a hormonal system that is largely comparable to that of vertebrates (Duft et al., 2007), and similar responses to diuron were expected. Although no statistically significant differences in fertility parameters were observed in this study, a slight increase in the total number of egg sacs was detected after 4 days of exposure. This increase appeared to be related to higher diuron concentrations. Because no statistical evidence was found, we cannot assert that diuron is responsible. The absence of clear differences could be due to the differences between in vitro and in vivo assays. A molecular response to the toxicant does not necessarily imply an immediate reproductive response.
Effects of diuron on vertebrates' behaviour have been reported. A previous experiment (Saglio \& Trijasse, 1998) found changes in the behaviour of the fish Carassius auratus exposed to different concentrations of diuron. Short-term exposure to $5 \mu \mathrm{gL}^{-1}$ produced direct and indirect changes by altering chemical perception. Another experiment with the same organism (Bretraud et al., 2000) reported inhibitory effects of diuron on the enzyme acetylcholinesterase in the brain of $C$. auratus at $5 \mu \mathrm{gL}^{-1}$ after 12 hours of exposure. More recently, Gagnaire et al., (2008) studied the activity of several isoforms of cholinesterase enzyme in freshwater snails exposed to chlorpyrifos, showing a decrease in enzyme activity in animals exposed to toxicants. Acetylcholine is the primary neurotransmitter in the sensory and neuromuscular systems of most species, and the activity of this enzyme is essential for normal muscular function (Fulton \& Key, 2001). Unfortunately, Gagnaire et al. (2008) did not study the effects on movement or behaviour, and no activities of tissues were investigated. These previous experiments led us to investigate whether diuron could affect the ability to search for food or the capacity to respond to disturbing stimuli in natural environments. In this study, snails did not exhibit different velocities in response to the different treatments; therefore, diuron had no effects on locomotive skills at these concentrations. In an experiment on the effects of the herbicide atrazine on $P$. acuta, exposed organisms exhibited changes in locomotive skills relative to control organisms. Exposed snails moved at higher velocities than did organisms in the control treatment (Rosés et $a l ., 1999)$, but this response was not directly due to the effects of atrazine on organisms but rather the indirect effects of atrazine on food resources.

The relative absence of severe effects of diuron on $P$. acuta could be explained by the protective action of mucus secretions, which might minimise the animal's exposure to diuron. As has been explained above, a qualitative increase in the volume of mucous secretory cells in the tegument of organisms exposed to diuron, as well as the accumulation of mucus in the water of aquaria at the highest concentration, 
were reported in our study. Mucus is composed of high-molecular-weight glycosylated proteins and is secreted by snails to protect their external tissues and facilitate movement (Denny, 1980) as well as to protect against pollutants (Davies, 1992; South, 1992). The massive release of mucus observed in water at high concentrations has been observed for exposure to other toxicants such as pharmaceuticals in terrestrial gastropods (Adriaens \& Remon, 1999), as well as in marine gastropods exposed to cadmium (Wicklum \& Davies, 1996). Increased secretion of mucus can prevent direct contact with diuron in water. However, the potential role of detoxification mechanisms cannot be neglected. Previous work with fish (Salmo gairdneri, Call et al., 1987) described low bioaccumulation and fast elimination of this herbicide ( $90 \%$ in $24 \mathrm{hrs}$ ), and Hayes (1982) describes metabolisation of diuron in mammals within hours by hydroxylation and $N$-dealkylation and excretion via urine. There is no information about the metabolic pathways of diuron in molluscs, but a similar mechanism of detoxification and excretion most likely exists.

\section{CONCLUSION}

Diuron, at concentrations similar to those found in freshwater environments $\left(9.5 \mu \mathrm{gL}^{-1}\right)$, causes sublethal effects in the freshwater snail P. acuta. Hyperplasia of mucopolysaccharide-secreting cells in the tegument and effects on $\mathrm{C}$ and $\mathrm{N}$ contents are reported. Effects on reproduction were not significant, but a slight increase in the total number of egg sacs was detected after 4 days of exposure.

\section{REFERENCES}

ABBOTT, B. D., G. H. PERDEW \& L. S. BIRNBAUM. 1994. Ah receptor in embryonic mouse palate and effects of TCDD on receptor expression. Toxicology and Applied Pharmacology, 126: $16-25$.

ADRIAENS, E. \& J. P. REMON. 1999. Gastropods as evaluation tool for screening the irritating potency of absorption enhancers and drugs. Pharmaceutical Research, 16: 1240-1244.
BARATA, C., C. PORTE \& D. J. BAIRD. 2004. Experimental designs to assess endocrine disrupting effects in invertebrates, a review. Ecotoxicology, 13: 511-517.

BEYERS, D. W., J. A. RICE, W. H. CLEMENTS \& C. J. HENRY. 1999. Estimating physiological cost of chemical exposure: integrating energetics and stress to quantify toxic effects in fish. Canadian Journal of Fisheries and Aquatic Sciences, 56: 814-822.

BRETRAUD, S., J. P. TUTANT \& P. SANGLiO. 2000. Effects of Carbofuran, Diuron, and Nicosulfuron on Acetylcholinesterase activity in Goldfish (Carassius auratus). Ecotoxicology and Environmental Safety, 47: 117-124.

CALL, D. J., L. T. BROOKE, R. J. KENT, M. L. KNUTH, S. H. POIRIER, J. M. HUOT \& A. R. LIMA. 1987. Bromacil and diuron herbicides: Toxicity, uptake, and elimination in freshwater fish. Archives of Environmental Contamination and Toxicology, 16: 607-613.

CALOW, P. 1991. Physiological costs of combating chemical toxicants: Ecological implications. Comparative Biochemistry and Physiology Part C: Comparative Pharmacology, 100: 3-6.

CARDONE, A., R. COMITATO \& F. ANGELINI. 2008. Spermatogenesis, epididymis morphology and plasma sex steroid secretion in the male lizard Podarcis sicula exposed to diuron. Environmental Research, 108: 214-223.

CENGIZ, E. I., M. Z. YILDIRIM, B. OTLUDIL \& E. ÜNLÜ. 2005. Histopathological effects of Thiodan ${ }^{\circledR}$ on the freshwater snail, Galba truncatula (Gastropoda, Pulmonata). Journal of Applied Toxicology, 25: 464-469.

CHRISTIAN, F. A. \& T. M. TATE. 1983. Toxicity of Fluometuron and Diuron on the Intermediate Sanil Host (Lymnea spp.) of Fasciola hepatica. Bulletin of Environmental Contamination and Toxicology, 30: 628-631.

CONNOR, K., K. RAMAMOORTHY, M. MOORE, M. MUSTAIN, I. CHEN, S. SAFE, T. ZACHAREWSKI, B. GILLESBY, A. JOYEUX \& P. BALAGUER. 1997. Hydroxylated polychlorinated biphenyls (PCBs) as estrogens and antiestrogens: structure-activity relationships. Toxicology and Applied Pharmacology, 145: 111-123.

CZECH, P., K. WEBER \& D. R. DIETRICH. 2001. Effects of endocrine modulating substances on reproduction in the hermaphroditic snail Lymnaea stagnalis L. Aquatic Toxicology, 53: 103-114. 
DAVIES, M. S. 1992. Heavy metals in seawater: effects on limpet pedal mucus production. Water Research, 26: 1691-1693.

DE CASTRO-CATALÀ, N., J. C. LÓPEZ-DOVAL, M. GORGA, M. PETROVIC \& I. MUÑOZ. 2013. Is reproduction of the snail Physella acuta affected by endocrine disrupting compounds? An in situ bioassay in three Iberian basins. Journal of Hazardous Materials, 15: 248-255.

DEFUR, P. L., M. CRANE, C. INGERSOLL \& L. TATTERSFIELD. 1999. Endocrine disruption in invertebrates: endocrinology, testing and assessment. SETAC. FL. USA.

DENNY, M. W. 1980. The role of gastropod pedal mucus in locomotion. Nature, 285: 160-161.

DUFT, M., C. SCHMITT, J. BACHMANN, C. BRANDELINK, U. SCHULTE-OEHLMANN \& J. OEHLMANN. 2007. Prosobranch snails as test organisms for the assessment of endocrine active chemicals - an overview and a guideline proposal for a reproduction test with the freshwater mudsnail Potamopyrgus antipodarum. Ecotoxicology, 16: 169-182.

EUROPEAN COMMISSION. 2007. Review report for the active substance diuron, SANCO/10542/ 2005. European Commission, Directorate E-Food Safety: Production and distribution chain, Unit E.3-Chemicals, contaminants and pesticides. Brussels, Belgique.

EVANS-WHITE, M. A., R. S. STELZER \& G. A. LAMBERTI. 2005. Taxonomic and regional patterns in benthic macroinvertebrate elemental composition in streams. Freshwater Biology, 50: 17861789.

FINK, P. \& E. VON ELERT. 2006. Physiological responses to stoichiometric constraints: nutrient limitation and compensatory feeding in a freshwater snail. Oikos, 115: 484-494.

FULTON, M. H. \& P. B. KEY. 2001. Acetylcholinesterase inhibition in estuarine fish and invertebrates as an indicator of organophosphorus insecticide exposure and effects. Environmental Toxicology and Chemistry, 20: 37-45.

GAGNAIRE, B., O. GEFFARD, B. XUEREB, C. MARGOUM \& J. GARRIC. 2008. Cholinesterase activities as potential biomarkers: Characterization in two freshwater snails, Potamopyrgus antipodarum (Mollusca, Hydrobiidae, Smith 1889) and Valvata piscinalis (Mollusca, Valvatidae, Muller 1774). Chemosphere, 71: 553-560.
GIACOMAZZI, S. \& N. COCHET. 2004. Environmental impact of Diuron transformation: a review. Chemosphere, 56: 1021-1032.

HAYES, W. J. 1982. Pesticides Studied in Man. Williams and Wilkins. Baltimore, MD. USA.

JURKIEWIEZ-KARNKOWSKA, E. 2005. Some aspects of nitrogen, carbon and calcium accumulation in molluscs from the Zegrzynski reservoir ecosystem. Polish Journal of Environmental Studies, 14: 173-177.

LAGADIC, L., M. A. COTELLEC \& T. CAQUET. 2007. Endocrine disruption in aquatic pulmonate molluscs: few evidences, many challenges. Ecotoxicology, 16: 45-59.

MATTHIESSEN, P. \& P. E. GIBBS. 1998. Critical appraisal of the evidence for tributyltin-mediated endocrine disruption in molluscs. Environmental Toxicology and Chemistry, 17: 37-43.

McMANUS, J. F. A. 1948. Histological and Histochemical Uses of Periodic Acid. Biotechnic and Histochemistry, 23: 99-108.

NEBEKER, A. V. \& G. S. SCHUYTEMA. 1998. Chronic effects of the herbicide Diuron on freshwater Cladoceran, Amphipods, Midges, Minnows, Worms and Snails. Archives of Environmental Contamination and Toxicology, 35: 441-446.

NOGUEROL, T. N., S. BORONAT, M. CASADO, D. RALDUA, D. BARCELO \&B. PIÑA. 2006. Evaluating the interactions of vertebrate receptors with persistent pollutants and antifouling pesticides using recombinant yeast assays. Analytical and Bioanalytical Chemistry, 385: 1012-1019.

OEHLMANN, J., U. SCHULTE-OEHLMANN, M. TILLMANN \& B. MARKERT. 2000. Effects of endocrine disruptors on prosobranch snails (Mollusca: Gastropoda) in the laboratory. Part I: Bisphenol A and octylphenol as xeno-estrogens. Ecotoxicology, 9: 383-397.

ORTON, F., I. LUTZ, W. KLOAS \& E. J. ROUTLEDGE. 2009. Endocrine disrupting effects of herbicides and pentachlorophenol: in vitro and in vivo evidence. Environmental Science and Technology, 43: 2144-2150.

PROIA, L., S. MORIN, M. PEIPOCH, A. M. ROMANI \& S. SABATER. 2011. Resistance and recovery of river biofilms receiving short pulses of Triclosan and Diuron. Science of the Total Environment, 409: 3129-3137.

RELYEA, R. \& J. HOVERMAN. 2006. Assessing the ecology in ecotoxicology: a review and synthesis 
in freshwater systems. Ecology Letters, 9: 11571171.

RODRÍGUEZ-MOZAZ, S., M. J. LÓPEZ DE ALDA \& D. BARCELÓ. 2004. Monitoring of estrogens, pesticides and bisphenol $\mathrm{A}$ in natural waters and drinking water treatment plants by solid-phase extraction-liquid chromatography-mass spectrometry. Journal of Chromatography A, 1045: 85-92.

ROSÉS, N., M. POQUET \& I. MUÑOZ. 1999. Behavioural and histological effects of Atrazine on freshwater molluscs (Physa acuta Drap. and Ancylus fluviatilis Müll. Gastropoda). Journal of Applied Toxicology, 19: 351-356.

SAGLIO, P. \& S. TRIJASSE. 1998. Behavioral responses to atrazine and diuron in goldfish. Archives of Environmental Contamination and Toxicology, 35: 484-491.

SANDERS, H. O. \& O. B. COPE. 1968. The relative toxicities of several pesticides to naiads of three species of stoneflies. Limnology and Oceanography, 13: 112-117.

SCHMITT, C., C. VOGT, B. VAN BALLAER, R. BRIX, A. SUETENS, M. SCHMITT-JANSEN \& E. DE DEKERE. 2010. In situ cage experiments with Potamopyrgus antipodarum - a novel tool for real life exposure assessment in freshwater ecosys- tems. Ecotoxicology and Environmental Safety, 73: 1574-1579.

SCHULTE-OEHLMANN, U., M. TILLMANN, B. MARKET \& J. OEHLMANN. 2000. Effects of Endocrine Disruptors on Prosobranch Snails (Mollusca: Gastropoda) in the Laboratory. Part II: Triphenyltin as Xeno-Estrogens. Ecotoxicology, 9: 399-412.

SOUTH, A. 1992. Structure of the tegument. In: Terrestrial slugs: biology, ecology and control. A. South (ed.): Chapman \& Hall, London, UK.

THURMAN, E. M., D. A. GOOLBY, M. T. MEYER \& D. W. KOLPIN. 1991. Herbicides in surface waters of the Midwestern United States: The effect of spring flush. Environmental Science and Technology, 25: 1794-1796.

TLILI, A., U. DORIGO, B. MONTUELLE, C. CARLUER, V. GOUY, A. BOUCHEZ \& A. BERARD. 2008. Responses of chronically contaminated biofilms to short pulses of Diuron. An experimental study simulating flooding events in a small river. Aquatic Toxicology, 87: 252-263.

WICKLUM, D. \& R. W. DAVIES. 1996. The effects of chronic cadmium stress on energy acquisition and allocation in a freshwater benthic invertebrate predator. Aquatic Toxicology, 35: 237-252. 